2013-01-01

\title{
Sustained Observation of Marine Biodiversity and Ecosystems
}

\author{
Vale M, HSJ
}

http://hdl.handle.net/10026.1/8301

10.4172/2332-2632.1000e101

Oceanography: Open Access

OMICS Publishing Group

All content in PEARL is protected by copyright law. Author manuscripts are made available in accordance with publisher policies. Please cite only the published version using the details provided on the item record or document. In the absence of an open licence (e.g. Creative Commons), permissions for further reuse of content should be sought from the publisher or author. 


\section{Sustained Observation of Marine Biodiversity and Ecosystems}

\section{Hawkins SJ ${ }^{1,2 *}$, Vale $M^{1,5,6}$, Firth LB ${ }^{3}$, Burrows $\mathrm{MT}^{4}$, Mieszkowska $\mathrm{N}^{2}$ and Frost $\mathrm{M}^{2}$}

${ }^{1}$ Ocean and Earth Science, National Oceanography Centre Southampton, Waterfront Campus, University of Southampton, European Way, Southampton, SO14 3ZH, UK ${ }^{2}$ Marine Biological Association of the UK, The Laboratory, Citadel Hill, Plymouth PL1 2PB, UK

${ }^{3}$ Ryan Institute, National University of Ireland, Galway, Ireland

${ }^{4}$ Scottish Association for Marine Sciences, Dunstaffnage Marine Laboratory, Oban, Argyll PA37 1QA, UK,

${ }^{5}$ CIIMAR/CIMAR - Interdisciplinary Centre of Marine and Environmental Research, University of Porto, Rua dos Bragas 289, 4050-123 Porto, Portugal

${ }^{6}$ CIRN - Centro de Investigação de Recursos Naturais dos Açores, Departamento Biologia, Universidade dos Açores, 9501-801 Ponta Delgada, S. Miguel, Açores,

Portugal

At a time of unprecedented global change it is essential to distinguish short-term and local scale variability ("noise") from the low-amplitude longer wavelength signal of climate-driven change. Moreover, global responses to climate need to be separated from regional and local scale impacts and their interactions better understood to enable effective management of marine ecosystems. In this short editorial, we make the case for sustaining long-term and broad-scale observations of the oceans and coastal waters. First we consider the value of longterm observations drawing on work in the Western English Channel $[1,2]$; before considering the challenges of sustaining time series and cautioning that such observations are at risk in any period of financial constraints for public sector research funding. We conclude by discussing their relevance to policy and marine management. This editorial is written primarily from an ecological and inshore perspective reflecting the experience of the lead author but the general issues discussed apply equally to work in the open ocean.

\section{Value of Long-Term and Broadside Observations}

Empirical observations of the physics, chemistry and biology of the oceans and coastal seas have been made since the last quarter of the $19^{\text {th }}$ Century, given impetus by the major oceanographic expeditions (e.g. Porcupine - 1868-1869, Challenger - 1872-1876, Hirondelle I and II - 1886-1922, Princesse Alice I and II - 1886-1922, National - 1889 and Valdivia -1898-1899) as well as the establishment of a network of coastal Marine Stations such as those in France (Station de Biologie Marine et Marinarium de Concarneau - 1859, Station Biologique de Roscoff - 1872, Observatoire Océanologique de Banyuls - 1881, Villefranchesur-mer Oceanological Observatory - 1882); Italy ( at Naples, Stazione Zoologica Anton Dohrn - 1872); Sweden (Kristineberg Marine Research Station - 1877); Great Britain (The Plymouth Laboratory of the Marine Biological Association - 1888, Port Erin Marine Laboratory - 1892, Marine Biological Station Millport - 1894); USA (Woods Hole Marine Biological Laboratory - 1888) and Germany (Biological Institute Helgoland - 1892). The International Investigations of the early 1900s led by the International Council for the Exploration of the Seas (ICES) was an early and important attempt to integrate and network the efforts of multiple nations. In the UK the Marine Biological Association of the United Kingdom (MBA) led the work from its Laboratories at Lowestoft and Plymouth. The work in the English Channel initiated a long-running, but much interrupted time-series. Wars, funding cuts, institutional re-organisation and changes in research priorities all took their toll at various times over the last century.

The Plymouth time-series (initially led by the MBA until 1987, with additional parameters measured by Plymouth Marine Laboratory (PML) (1987-2007), consolidated as the Western Channel Observatory www.westernchannelobservatory.org.uk in 2007, has made some major contributions to marine science over the last 100 years. One of the strengths of the Western English Channel time-series is its comprehensive nature covering physical, chemical measurements and observations of various biological compartments (phytoplankton, zooplankton, fish, benthos, intertidal assemblages) [1-6] of the ecosystem and its grid nature with two to three main stations E1, L5, L4 [2] on an inshore-offshore axis with both stratified and mixed water bodies. Observations in the Western English Channel have shown how climate fluctuations can drive whole nearshore and coastal ecosystems [3,4,7-10]. These were apparent long before the recent spell of rapid warming since the late 1980s [1,2] and were coined "the Russell Cycle" by Cushing and Dickson [11]. Thus they provide a true fluctuating baseline of colder (early part of $20^{\text {th }}$ Century, 1962-1987) and warmer (1930s to 1960) periods against which to judge subsequent rapid climate-driven change since the late 1980s. Recent examination of the long-term data suggests that the Russell Cycle may reflect the Atlantic Multidecadal Oscillation (AMO) [12]. Early ideas about the relative importance of top-down control versus bottom-up forcing stemmed from this work [13]. More recently the time-series has been used to show the response of whole bottom; fish assemblages to climate change [14], enabling the separation of climate change and fishing impacts [15]. There have been major switches in pelagic fish: from herrings in cold periods to pilchards (also called sardines) in warmer periods, which historical analysis showed stretched back to the Middle Ages [16]. Interestingly there was not a major return to herring in the cold period of the 1960s to late 1980s; perhaps because of overexploitation of herring in much of Europe restricting source populations [1]. These changes in fish were also accompanied by changes in the zooplankton with shifts between typical of northern offshore assemblages to those typical of warmer and more inshore waters, thereby suggesting a broad change in the ecosystem rather than the influence of overfishing [4]. Periodic re-surveys have shown the influence of fishing disturbance on benthic assemblages with a shift from larger organisms such as bivalves to smaller polychaetes from the 1950 s $[7,17]$ compared to the 2000 s [18].

Changes offshore have been mirrored by those in the intertidal zone $[19,20]$. Many marine invertebrates have extensive larval periods spent in inshore waters and subsequent recruitment success can reflect

*Corresponding author: Stephen J. Hawkins, Ocean and Earth Science National Oceanography Centre Southampton, Waterfront Campus, University of Southampton, European Way, Southampton, SO14 3ZH, UK, Tel: (023) 8059 3596; E-mail: S.J.Hawkins@soton.ac.uk

Received January 24, 2013; Accepted January 25, 2013; Published January 28 , 2013

Citation: Hawkins SJ, Vale M, Firth LB, Burrows MT, Mieszkowska N, et al. (2013) Sustained Observation of Marine Biodiversity and Ecosystems. Oceanography 1: e101. doi:10.4172/ocn.1000e101

Copyright: ( 2013 Hawkins SJ, et al. This is an open-access article distributed under the terms of the Creative Commons Attribution License, which permits unrestricted use, distribution, and reproduction in any medium, provided the original author and source are credited. 
nearshore conditions. Because of the rich history of experimental ecology on rocky shores, processes are well understood. Frameworks have been developed to better predict the impacts of future species range changes on community structure and functioning [21]. Furthermore, the coupling of this knowledge of process with statistical treatment of 40-year data sets [5,22] has enabled predictive modelling [23]. This work has shown how the northern cold-water species of barnacle (Semibalanus balanoides) will be replaced by southern warmwater species (Chthamalus spp.) under various future climate scenarios as warmer weather releases the slower growing southern species from competition due to mortality during recruitment. No doubt similar processes will be occurring in less tractable offshore species as climate change modulates biological interactions.

\section{Challenges with Long Term Data Collection}

One of the major challenges of maintaining time-series from a technical perspective is internal consistency of methodology, especially in the face of technological change and development of new techniques. This is particularly the case with chemical measurements such as nutrients. Joint et al. [24] demonstrated real deficiencies in the measurement of nutrients in the 1920s and 1930s compared to current practise (although well audited methodologies allow for some recalibration and cross-calibration). This means some interpretations of shifts in ecosystem functioning [4] have to be viewed with caution as differences in nutrients were likely to have been due to changes in methodology.

Some measurements such as temperature and salinity are very simple and whilst there may be improvements in precision they are still sufficiently accurate to enable comparisons over centurylong time scales. There should also be a caution that sea surface temperature measured by satellites, whilst incredibly valuable, must be complemented by shipboard, drifter or buoy-gathered data. In particular routine bottom seawater temperatures are invaluable. For example, Sims et al. [25] showed that timing of squid migrations were correlated with sea bottom temperatures.

Fortunately, plankton and fishing nets have changed little over the last 130 years. Providing deployment, mesh size and towing speeds are consistent, both quantitative and qualitative comparisons can be made. It is important, however, that standard operating procedures are followed and that there are lead scientists acting as champions of the data sets for long periods.

The MBA time-series had two key figures: Russell from the 1920s to the 1970s and Southward from the 1950s to the late 1980s. Moreover, Southward's involvement with Hawkins and others was essential for restart of the time-series in the 1990s and 2000s. Many other laboratory staff were involved over the years (e.g. Garstang, Steven - fish; Boalch - phytoplankton and primary production measurements; and Corbyn zooplankton) as well as expert support staff (Mattacola and well trained ships crews). In some cases catch logs maintained by non-scientist crews of research vessels have led to interesting publications on phenology $[25,26]$. The Dove time-series collected by the University of Newcastle (NE England), owed much to Buchanan, Evans and latterly Frid [2731]. The Port Erin Marine Laboratory hydrography and nutrient timeseries was built by Slinn $[27,32]$. Wulf was the stalwart and steward of the Helgoland time-series [30] now taken on by Wiltshire [33]. With internal consistency and training and baton-passing to new generations of staff, such time-series can be maintained - but this is not always easy. They are particularly vulnerable to retirement (voluntary and forced) and departure of key staff or the inability to develop new champions.
The other major vulnerability is that time-series are often viewed in some quarters as being merely monitoring exercises, and not addressing hypothesis-testing research. Certainly, the work by Southward in Plymouth did test hypotheses about the underlying role of climatic fluctuations in driving change. Moreover, sustained observing of temporal patterns often generates hypotheses for subsequent testing by shorter-term targeted cruises or experiments in the field or laboratory. Most importantly, long-term and broad-scale data can be used to calibrate and validate modelling exercises [23,34].

The biggest challenge is getting and maintaining "long thin" funding and ensuring continuity to sustain observing. Low-cost programmes using ships of opportunity have been the platform for both physical and biological observing programmes - in the latter case the Continuous Plankton Recorder (CPR) Survey operated by the Sir Alister Hardy Foundation for Ocean Science. This survey was closed down by the UK's Natural Environment Research Council (NERC) in the late 1980s, but immediately rescued as a charitable foundation. Pleasingly, it now receives core NERC support and the data gathered has led to some exceptional papers informing our knowledge of the responses of marine ecosystems to climate change [35-38].

Sustained observations are often strongest when networked at regional, national, super-national (i.e. the EU) and internationally. This enables both long-term and broad-scale coverage and congruence of trends to be detected and measured. In the UK the Marine Environmental Change Network (MECN - www.mba.ac.uk/mecn) enabled the re-start of time-series and has latterly enabled analysis of multiple data sets [39] to critically evaluate whether the regime shifts have occurred or not. Similar efforts have been pursued by the LargeNet programme resulting from the European MARBEF Network of Excellence (www.marbef.org/projects/largenet/index.php) [40].

\section{Policy Relevance}

Long-term data are essential for informing a precautionary approach in managing fisheries as overfishing and climate change usually interact to the detriment of cold water species. There is however, the potential for new fisheries to develop when warm-water species expand pole-wards $[41,42]$. Low biomass stocks that have been fished down can be less resilient to climate change. Phenological mismatches due to climate change can lead to recruitment failure $[30,38,43]$. Understanding undergoing long-term change can reduce uncertainty in managing fish stocks [41].

Long-term data are essential to understand both regional and localscale eutrophication, particularly in separating broader oceanographic drivers from processes internal to the catchment of enclosed seas $[32,44]$. Often a combination of particular hydrographic conditions such as warm sunny weather enhancing stratification and higher nutrients due to eutrophication lead to blooms of harmful algal species $[45,46]$. Long-term data can be used to quantify whether the frequency of such events has increased or not.

Coming inshore, condition monitoring of areas of conservation interest (e.g. Special Areas of Conservation (SACs)) requires separation of local impacts from broader change. For example, has a species decreased in abundance due to climate driven change (impossible to manage) or to some local impact such as habitat loss or degradation which is manageable, and therefore reversible?

Much national and international marine policy is formulated with the long-term objective of having "clean, healthy, safe productive and biologically diverse oceans and seas" and with specific targets for with 
Citation: Hawkins SJ, Vale M, Firth LB, Burrows MT, Mieszkowska N, et al. (2013) Sustained Observation of Marine Biodiversity and Ecosystems. Oceanography 1: e101. doi:10.4172/ocn.1000e101

which to measure status [47]. Without long-term data there is no way of charting progress [48] towards these objectives or knowing which management and adaptation measures are appropriate for implementation. For example, in European marine waters the Marine Strategy Framework Directive has been adopted with the goal being to meet 'Good Environmental Status' by 2020. The specific target for biodiversity is that 'Biological diversity is maintained'. However, the second part of its target states 'The quality and occurrence of habitats and the distribution and abundance of species are in line with prevailing physiographic, geographic and climate conditions'. The need to understand natural variability as measured by long-term observations is therefore vital as these 'prevailing conditions' will be subject to much variability at large spatial and temporal scales.

In the UK, the Marine Climate Change Impact Partnership (MCCIP), is a good example of a programme that has drawn heavily on long-term studies in its work engaging with policy makers to inform adaptative response and management (as well as communicating with the general public) [49].

\section{Concluding Comments}

Long-term data sets are invaluable but yet vulnerable; especially in the current funding regime. Often their value is only appreciated when the time-series ceases. They can, however be easily re-started as demonstrated by the Western English Channel time-series and despite gaps, still provide extremely valuable data. A major challenge for the marine science community is to sustain observing, building on the foresight of those early pioneers of oceanography and marine biology of the late $19^{\text {th }}$ century. There is a danger that the current emphasis on sharing and re-using data has diverted attention from the need to maintain long-term data-sets. Sustained observing, suitably networked provides the basic data to enable forecast and hopefully prediction of the future status of the ocean.

\section{Acknowledgements}

S.J. Hawkins, M. Frost, N. Mieszkowska and M.T. Burrows were funded by the MarClim project (English Nature; Scottish Natural Heritage; Countryside Council for Wales; Environment Agency; The Scottish Executive; States of Jersey Department for Environment, Food, and Rural Affairs; The Crown Estate; Join Nature Conservation Committee; and World Wildlife Fund) and the Defra funded Marine Environmental Change Network.

S.J. Hawkins, N. Mieszkowska and M.T. Burrows were also funded by the NERC VOCC Project. The work also benefitted from support from NERC's Oceans 2025 Programme.

M. Vale was supported by a PhD Grant awarded by Fundação para a Ciência e Tecnologia, (FCT, Portugal) (SFRH/BD/70374/2010) and also partially supported by the European Regional Development Fund (ERDF) through the COMPETE - Operational Competitiveness Programme and national funds through FCT - Foundation for Science and Technology, under the project "PEst-C/MAR/ LA0015/2011.

We thank Alan Southward for inspiring our interest in long-term research.

\section{References}

1. Hawkins SJ, Southward AJ, Genner MJ (2003) Detection of environmental change in a marine ecosystem - Evidence from the western English Channel. Sci Total Environ 310: 245-256.

2. Southward AJ, Langmead O, Hardman-Mountford NJ, Aiken J, Boalch GT, et al. (2005) Long-term oceanographic and ecological research in the Western English Channel. Adv Mar Biol 47: 1-105.

3. Southward AJ (1963) The distribution of some plankton animals in the English Channel and approaches. III. Theories about long-term biological changes, including fish. J Mar Biol Assoc UK 43: 1-29.

4. Southward AJ (1980) The western English Channel - An inconsistent ecosystem? Nature 285: 361-366.
5. Southward AJ, Hawkins SJ, Burrows MT (1995) Seventy years' observations of changes in distribution and abundance of zooplankton and intertidal organisms in the Western English channel in relation to rising sea temperature. J Therm Biol 20: 127-155

6. Russell FS, Southward AJ, Boalch GT, Butler El (1971) Changes in biological conditions in the English Channel off Plymouth during the last half century. Nature 234: 468-470.

7. Holme NA (1961) The bottom fauna of the English Channel. J Mar Biol Assoc UK 41: 397-461.

8. Russell FS (1973) A summary of observations on the occurrence of planktonic stages of fish off Plymouth 1924-1972. J Mar Biol Assoc UK 53: 347 -355.

9. Holme NA (1983) Fluctuations in the Benthos of the Western English Channel. Proceedings of the 17th European Marine Biology Symposium Oceanologia Acta.

10. Holme NA (1984) Fluctuations of Ophiothrix fragilis in the Western English Channel. J Mar Biol Assoc UK 64: 351-378.

11. Cushing DH, Dickson RR (1977) The biological response in the sea to climatic changes. Adv Mar Biol 14: 1-122.

12. Mieszkowska N, Burrows MT, Pannacciulli FG, Hawkins SJ (2013) Multidecada signals within co-occurring intertidal barnacles Semibalanus balanoides and Chthamalus spp. linked to the Atlantic Multidecadal Oscillation. J Marine Syst.

13. Cushing DH (1961) On the failure of the Plymouth Herring Fishery. J Mar Bio Assoc UK 41: 799-816

14. Genner MJ, Sims DW, Wearmouth VJ, Southall EJ, Southward AJ, et al. (2004) Regional climate warming drives long-term community changes of British marine fish. P Roy Soc Lond B Bio 271: 655-661.

15. Genner MJ, Sims DW, Southward AJ, Budd GC, Masterson P, et al. (2010) Body size-dependent responses of a marine fish assemblage to climate change and fishing over a century-long scale. Glob Change Biol 16: 517-527.

16. Southward AJ, Boalch GT, Maddock L (1988) Fluctuations in the herring and pilchard fisheries of Devon and Cornwall linked to change in climate since the 16th century. J Mar Biol Assoc UK 68: 423-445.

17. Holme NA (1953) The biomass of the bottom fauna in the English Channel off Plymouth. J Mar Biol Assoc UK 32: 1-49.

18. Capasso E, Jenkins SR, Frost M, Hinz H (2010) Investigation of benthic community change over a century-wide scale in the Western English Channel. J Mar Biol Assoc UK 90: 1161-1172.

19. Helmuth B, Mieszkowska N, Moore P, Hawkins SJ (2006) Living on the Edge of Two Changing Worlds: Forecasting the Responses of Rocky Intertida Ecosystems to Climate Change. Annu Rev Ecol Evol Syst 37: 373-404.

20. Mieszkowska N, Kendall MA, Hawkins SJ, Leaper R, Williamson P, et al. (2006) Changes in the range of some common rocky shore species in Britain a response to climate change? Marine Biodiversity 183: 241-251.

21. Firth LB, Crowe TP, Moore P, Thompson RC, Hawkins SJ (2009) Predicting impacts of climate-induced range expansion: An experimental framework and a test involving key grazers on temperate rocky shores. Glob Change Biol 15 1413-1422.

22. Southward AJ (1991) Forty years of changes in species composition and population density of barnacles on rocky shore near Plymouth. J Mar Biol Assoc UK 71: 495-513.

23. Poloczanska ES, Hawkins SJ, Southward AJ, Burrows MT (2008) Modeling the response of populations of competing species to climate change. Ecology 89: $3138-3149$

24. Joint I, Jordan MB, Carr MR (1997) Is phosphate part of the Russell cycle? J Mar Biol Assoc UK 77: 625-633.

25. Sims DW, Genner MJ, Southward AJ, Hawkins SJ (2001) Timing of squid migration reflects North Atlantic climate variability. P Roy Soc Lond B Bio 268 2607-2611.

26. Sims DW, Wearmouth VJ, Genner MJ, Southward AJ, Hawkins SJ (2004) Lowtemperature-driven early spawning migration of a temperate marine fis. J Anim Ecol 73: 333-341.

27. Slinn DJ (1974) Water circulation and nutrients in the north-west Irish sea. Estuarine, Coastal and Marine Science 2: 1-25. 
Citation: Hawkins SJ, Vale M, Firth LB, Burrows MT, Mieszkowska N, et al. (2013) Sustained Observation of Marine Biodiversity and Ecosystems. Oceanography 1: e101. doi:10.4172/ocn.1000e101

28. Buchanan JB, Moore JJ (1986) A broad review of variability and persistence in the Northumberland benthic fauna - 1971-1985. J Mar Biol Assoc UK 66: 641-657.

29. Frid CLJ, Buchanan JB, Garwood PR (1996) Variability and stability in benthos: twenty-two years of monitoring off Northumberland. ICES J Mar Sci 53: 978980

30. Greve W, Reiners F, Nast J, Hoffmann S (2004) Helgoland Roads meso- and macrozooplankton time-series 1974 to 2004: Lessons from 30 years of single spot, high frequency sampling at the only off-shore island of the North Sea. Helgoland Mar Res 58: 274-288.

31. Frid CLJ (2011) Temporal variability in the benthos: Does the sea floor function differently over time? J Exp Mar Biol Ecol 400: 99-107.

32. Allen JR, Slinn DJ, Shammon TM, Hartnoll RG, Hawkins SJ (1998) Evidence for Euthrophication of the Irish Sea over four decades? Limnol Oceanogr 43: 1970-1974.

33. Wiltshire KH, Malzahn AM, Wirtz K, Greve W, Janisch S, et al. (2008) Resilience of North Sea Phytoplankton Spring Bloom Dynamics: An analysis of long-term data at Helgoland Roads. Limnol Oceanogr 53: 1294-1302.

34. Araújo JN, Mackinson S, Stanford RJ, Sims DW, Southward AJ, et al. (2006) Modelling food web interactions, variayion in plankton production, and fisheries in the western English Channel ecosystem. Mar Ecol-Prog Ser 309: 175-187.

35. Beaugrand G, Reid PC, Ibañez F, Lindley JA, Edwards E (2002) Reorganization of North Atlantic Marine Copepod Biodiversity and Climate. Science 296: 16921694

36. Beaugrand G, Reid PC (2003) Long-term changes in phytoplankton, zooplankton and salmon related to climate. Glob Change Biol 9: 801-817.

37. Beaugrand G, McQuatters-Gollop A, Edwards M, Goberville E (2012) Longterm responses of North Atlantic calcifying plankton to climate change. Nature Climate Change.

38. Edwards M, Richardson AJ (2004) Impact of climate change on marine pelagic phenology and trophic mismatch. Nature 430: 881-884.
39. Spencer M, Birchenough SNR, Mieszkowska N, Robinson LA Simpson SD, et al. (2011) Temporal change in UK marine communities: trends or regime shifts? Mar Ecol 32: 10-24.

40. Kraberg AC, Wasmund N, Vanaverbeke J, Schiedek D, Wiltshire $\mathrm{KH}$, et at. (2011) Regime shifts in the marine environment: The scientific basis and political context. Mar pollut bull 62: 7-20.

41. Cheung WWL, Pinnegar J, Merino G, Jones MC, Barange M (2012) Review of climate change impacts on marine fisheries in the UK and Ireland. Aquatic Conservation: Marine and Freshwater Ecosystems 22: 368-388.

42. Heath MR, Neat FC, Pinnegar JK, Reid DG, Sims DW, et al. (2012) Review of climate change impacts on marine fish and shellfish around the UK and Ireland. Aquatic Conservation: Marine and Freshwater Ecosystems 22: 337-367.

43. Moore PJ, Thompson RC, Hawkins SJ (2011) Phenological changes in intertidal con-specific gastropods in response to climate warming. Glob Change Biol 17: 709-719

44. Gowen RJ, Tett $P$, Kennington K, Mills DK, Shammon TM, et al. (2008) The Irish Sea: It is eutrophic? Estuarine, Coastal and Shelf Science 76: 239-254.

45. Anderson DM, Glibert PM, Burkholder JM (2002) Harmful Algal Blooms and Eutrophication: Nutrient Sources, Composition, and Consequences. Estuaries 25: 704-726.

46. Anderson DM, Burkholder JM, Cochlan WP, Glibert PM, Gobler CJ, et al. (2008) Harmful algal blooms and eutrophication: Examining linkages from selected coastal regions of the United States. Harmful Algae 8: 39-53.

47. Frost M (2010) Assessing the status of the Seas and Oceans: Determining the roles of Science and Policy. Biologia Marina Mediterranea 17: 6-10.

48. UK Marine Monitoring and Assessment Strategy (2010) Charting Progress 2 An assessment of the state of UK seas.

49. Frost M, Baxter JM, Buckley PJ, Cox M, Dye SR, et al. (2012) Impacts of climate change on fish, fisheries and aquaculture. Aquatic Conservation: Marine and Freshwater Ecosystems 22: 331-336.
Citation: Hawkins SJ, Vale M, Firth LB, Burrows MT, Mieszkowska N, et al. (2013) Sustained Observation of Marine Biodiversity and Ecosystems. Oceanography 1: e101. doi:10.4172/ocn.1000e101
Submit your next manuscript and get advantages of OMICS Group submissions

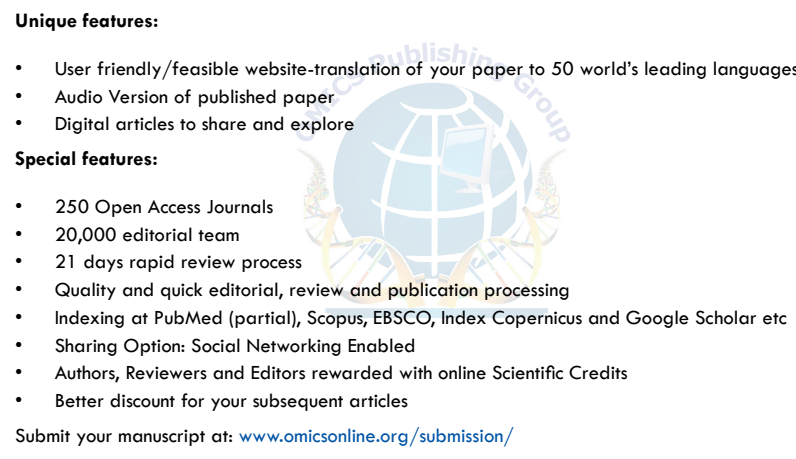

